\title{
26 Research Square \\ New insights on the genetic origins of lighter horse coats
}

\author{
H. M. Holl K. M. Pflug K. M. Yates K. Hoefs-Martin C. Shepard D. G. Cook C. Lafayette S. A. Brooks
}

\section{Video Byte}

Keywords: horse, genetics, color, coat, cremello, dilution, pearl, Etalon diagnostics, Animal Genetics, pigment, cream, double dilute, Wiley

Posted Date: December 23rd, 2019

DOI: https://doi.org/10.21203/rs.2.19669/v1

License: (c) (i) This work is licensed under a Creative Commons Attribution 4.0 International License. Read Full License 


\section{Abstract}

Equine genetics reveals otherwise invisible traits linked to your horse's appearance Several dilution genes -which lighten pigments in skin, eyes and hair-have been identified The SLC45A2 gene affects red and black pigments, creating cream and pearl coats But there are still gaps in the genetic story behind these coat colors Now, researchers have identified two new SLC45A2 variants One originated in medieval times and gives rise to the well-known pearl dilution The other-whose origin is unknown-produces a similar but entirely new dilution dubbed "sun" This research suggests that there's much more to learn in equine genetics and the results can empower breeders and owners to provide the best care for their horses Holl et al. "A candidate gene approach identifies variants in SLC45A2 that explain dilute phenotypes, pearl and sunshine, in compound heterozygote horses." Anim Genet. (2019) 